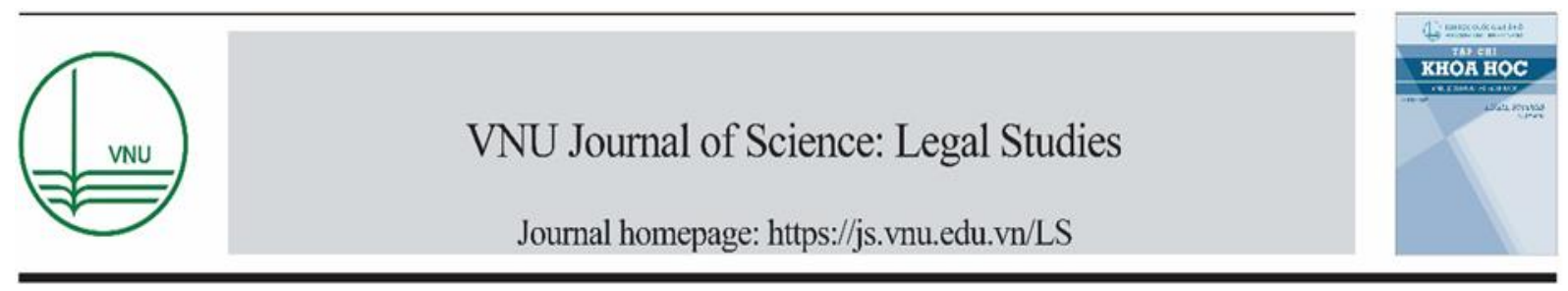

\title{
Review Article \\ Juvenile Victims in Vietnam Criminal Justice: Where to be and Where to go?
}

\author{
Le Lan Chi* \\ VNU School of Law, 144 Xuan Thuy, Cau Giay, Hanoi, Vietnam
}

Received 15 April 2021

Revised 17 May 2021; Accepted 24 June 2021

\begin{abstract}
Juvenile victims, a highly vulnerable group in criminal justice, are subject to damages caused by crime as well as the suffering caused by criminal proceedings. This paper is devoted to the clarification of the legal status of juvenile victims based on the combination of two statuses, namely the aggrieved person and minor in Vietnamese criminal justice, clarification of their legal status in Vietnamese traditional and contemporary legal culture, thereby making comparisons with the norms of international law. Accordingly, this paper indicates a great deal of attention given by the Vietnamese criminal procedure law to such group, despite several provisions that need to be further adjusted towards a new approach to minors and especially crime victims in the future.
\end{abstract}

Keywords: Juvenile, aggrieved persons, victims, criminal justice, Vietnam.

\section{Introduction}

Legal status of juvenile victims in Vietnam has not been clearly defined in terms of theory as well as in current legislation. This paper raises the questions as to where the position of juvenile victims at the present time is, which legal status they hold in Vietnamese criminal proceedings, where their position will be, and how the law should be further amended? To answer this key question, a range of issues revolving around their legal status need to be clarified, which include i) about the juvenile victims as the crime victims, whether this status

\footnotetext{
* Corresponding author.

E-mail address: lechilan@gmail.com

https://doi.org/10.25073/2588-1167/vnuls.4351
}

is concurrently considered the aggrieved person in criminal proceedings or not, ii) about the juvenile victims holding the legal status of the juvenile participants in criminal proceedings, how they are treated in comparison with adults and with other juvenile participants, iii) what the position of juvenile victims is in Vietnamese traditional and contemporary legal culture as well as in the interaction between Vietnamese law and international norms and standards ${ }^{1}$ pertaining to the rights of crime

\footnotetext{
${ }^{1}$ International norms compared in the paper are intensive provisions/standards of international human rights law on victims' rights and juvenile rights, especially: 1, Declaration of basic principles of justice for victims of crime and abuse of power, adopted by the United Nations
} 29 
victims and juveniles in criminal justice. This paper consists of 3 parts corresponding to 3 foregoing questions, with the primary focus being part 3 in order to evaluate and thus suggest the next steps in the process of legal acculturation to improve law in regard to legal status of juvenile aggrieved persons.

\section{Juvenile Victims as Victims, the Aggrieved Party in Criminal Justice}

Victims of a crime, in a broad sense, are understood as individuals or organizations, agencies, communities suffered from physical or mental harm or harm of their property as well as other legitimate rights and interests as a direct consequence of criminal offense. In the other word, "Victim of crime are persons suffered from loss of life, health, mental and emotional or economic loss, or harm of their other legitimate rights and interests directly caused by criminal offense" $[1 ; 164]^{2}$. There are not only "direct" victims, who are directly harmed and targeted by the criminals' initial

November 29, 1985 (hereinafter referred to as "Declaration"); 2, Guidelines for Action on Children in the Criminal Justice System, recommended by Economic and Social Council in Resolution 1997/30 dated 21 July 1997 (hereinafter referred to as "Guidelines"); 3, Directive of the European Parliament and the Council of 25 October 2012 establishing minimum standards on the rights, support and protection of victims of crime (hereinafter referred to as "Directive"); 4, Model law and related Judicial comments, relating to child victims and child witness of UNODC in 2009 (hereinafter referred to as "Model Law"). These legal instruments provide legal frameworks, minimum standards, and recommendations based on Universal Declaration on Human Rights 1948, International Covenant on Civil and Political Rights 1966 and Convention on the Rights of the Child 1989. In addition, some other international universal norms of human rights in criminal proceedings such as right to presumption of innocence, right to a fair trial and without undue delay... are also referred to collate with Vietnam legislation.

${ }^{2}$ Such approach is similar to the definition of "victim shall mean a natural person who has suffered harm, including physical or mental injury, emotional suffering or economic loss, directly caused by acts or omissions that are in violation of the criminal law of a Member State" under Framework Decision on the standing of victims in criminal proceedings, which was then superseded by the "Directive". purpose in committing crime but also the groups of "indirect victims" that are not targeted by the offenders but suffer from damages in direct relation to the offense. In a broader sense, the term "victim" also includes, where appropriate, the immediate family or dependents of the direct victim and persons who have suffered harm in intervening to assist victims in distress or to prevent victimization" [2].

Victim status objectively exists. In legal language in Vietnam, there appears another concept in the criminal procedure law that is really similar but not the same as the concept of victim of crime, which is the concept "bi hai" (temporarily translated hereinafter as "the aggrieved person" in English). "The aggrieved person" is a procedural status of victims and whether the victims are considered "the aggrieved party" in criminal proceedings or not depends on the will of the State (in terms of legislation and in practice - enforcement of law by procedure-conducting agencies).

From a legislative standpoint, that the victims have no status of being the aggrieved persons but of other participants in the proceedings first depends on the will of the legislators, on the regulations of each nation [2; Section 20], and Vietnam is a typical example for the model where status of victims is categorized into different procedural statuses and victims are basically entitled to only one procedural status. Some victims are conferred the status of aggrieved party but some are entitled to other procedural statuses other than the aggrieved party such as civil plaintiff [3; Article 63] ${ }^{3}$, legal representative of the aggrieved party [3; Article 62] $]^{4}$, and the witness

\footnotetext{
${ }^{3}$ Under Article 63 of the Vietnam Criminal Procedure Code of 2015, civil plaintiffs are persons and organizations suffering from damage caused by criminal acts and filing damage claim. Despite not being the target of crime, civil plaintiffs suffer from harm that stems from criminal offence and they participate in proceedings to pursue a civil lawsuit in a criminal case. The procedureconducting agencies only recognize their procedural status when they have a petition for compensation (civil lawsuit). ${ }^{4}$ Under Article 62 of the Vietnam Criminal Procedure Code of 2015, in case the aggrieved party dies, is missing, or has limited legal capacity, its representative shall
} 
[3; Article 66] $]^{5}$. Meanwhile, in addition to the status of the aggrieved party which is entitled to relatively full rights of victims, the other statuses do not have or do not have full rights of the victims ${ }^{6}$. This is a disadvantage for the victims of crime. Especially in comparison with other nations, no separate law on victims of crime has been enacted in Vietnam in order to set out regulations pertaining to the rights and protective measures to ensure the rights of victims, whether or not they participate in criminal proceedings regardless of their procedural status.

It can be said that the status of the aggrieved persons is narrower than that of the crime victim or, in other words, the aggrieved persons are a part of the crime victims. The rights of victims of crime are regulated in criminal procedure law and other relevant laws. The criminal procedure law stipulates the rights and some obligations of victims with corresponding procedural statuses (as mentioned) and these rights are mainly procedural rights. Moreover, some rights of victims of crime are provided in other laws (civil law, law on domestic violence prevention, law on human trafficking prevention, law on legal aid, etc. The aggrieved parties have almost all rights of victims as prescribed in criminal procedure code and other relevant laws because: procedural rights of the aggrieved persons are established in the way that covers other rights which are enjoyed and will be exercised by victims as provided in other laws (for example: right to compensation, right to protection, right to legal aid in certain circumstances). On the other hand, there are

execute its rights and duties and the representative is often a next of kin of the aggrieved party in such cases.

${ }^{5}$ Under Article 66 of the Vietnam Criminal Procedure Code of 2015, witnesses are those who know facts relating to the crime and criminal case and a subpoena to testify from competent procedural authorities. The aggrieved party is not considered as the witness and shall not assume the obligations of the witness.

6 Refer to: Article 63, 66 of the Vietnam Criminal Procedure Code of 2015 about the rights and obligations of civil plaintiff, and witness. procedural rights exclusively given to the aggrieved persons, and victims who are not the aggrieved parties shall not be entitled to such rights.

In practice, the status of crime victim appears upon the harm incurred by victims as a result of criminal offenses and is maintained before, during and after settlement of the criminal case, irrespective of whether their victimization becomes a criminal case and the offenders are prosecuted or not (a person shall be deemed to be victim regardless of whether the offenders are detected, detained, prosecuted, convicted or not and whether the offenders and victims are family members or not [2; Article 2]). Meanwhile, the aggrieved party, as a procedural status of crime victims and a type of procedural participants in the settlement of a specific criminal case, have their procedural status only when they are recognized by law enforcement activities of competent procedural authorities. The status as the aggrieved party wentitled to crime victims depends on the capacity, qualification and work ethics of procedureconducting persons in specific criminal cases. In other words, the status of aggreieved parties of victims depends primarily on whether procedure-conducting agencies prosecute the criminal case and whether their status as aggrieved party is recognized or not. This is not easy for juvenile victims because they are at a young age, thus having limited capacity in denunciation and denouncement of crime, as well as in the gathering of evidences of crime or damages caused by crime. Therefore, as stipulated by criminal procedure law, there appears another person, often the family leader, as the legal representative of juvenile victims to represent them in procedural relations. However, what matters is that the legal representative status is only determined when procedure-conducting agencies recognize juvenile victim as the aggrieved party. On the other hand, the will of juvenile victims is presented to procedure-conducting 
agencies via the head of the family. Such intermediaries may not accurately present the will of juvenile victims but instead, show their own will. The head of the family may stay silent or compromise with offenders as a trade-off of the interests of juvenile victims for reputation, prestige or economic benefits, then give up the right to denunciation of crime and accusation. This stands as another obstacle to the juvenile's transition from victims to the aggrieved persons.

\section{Juvenile Vvictims as Juvenile Participants in Criminal Justice}

Juvenile aggrieved persons are entitled to all rights acquired by the aggrieved parties in criminal proceedings. However, the law has its own rules, tailoring to unique features of juvenile aggrieved persons that the other aggrieved ones do not have. This can be attributed to the weaker position of juvenile aggrieved persons, also considered a vulnerable group, which results in their entitlement to special criminal policies.

The age of juveniles may vary according to different jurisdictions; however, one thing in common is that because of their young age, juveniles do not reach complete psychological and physiological development; their social awareness is still limited, so they are easily enticed to commit crime. On the other hand, because of their limited social awareness and experience, juveniles are at the risk of being victimized and harmed by criminals; after that, juveniles are likely to encounter more vulnerability due to the lack of skills and experience compared to adults to overcome damages caused by the crime $[4 ; 26]$.

Thus, juveniles are among the disadvantaged groups in criminal proceedings, like women, the elderly, ethnic minority, LGBT group, the physically or psychologically disadvantaged, etc.). They receive more care and are entitled to criminal legal policies and procedural legal policies with higher priorities. The question is
1) whether or not there is a conflict between these higher priorities with the principle of equality (or the principle of ensuring equality before the law, which is a fundamental principle) [5; Article 16], [3; Article 9] and 2), whether priorities given by the law to the juvenile are a manifestation of the humanity of the law, the principle of humanity which is a relatively traditional and common conception in Vietnam, especially accepted by legal practitioners in criminal justice system like "the juvenile are entitled to clemency and humanity policy of the government from the criminal perspective or criminal procedure perspective" $[5 ; 345]^{7}$.

To give answer to this special criminal policy applied to the juvenile in particular and the vulnerable people in general, human rights approach or human rights theory in the international human rights law is required. Accordingly, in the international human rights law, the aggrieved persons belong to the vulnerable group; therefore, like the juvenile accused who belong to the group as such, they must receive due concern by being given policies, and regulations of laws to be equal in their access to justice. Priorities given to the juvenile in general and juvenile aggrieved persons in particular are not only the exhibition of humanitarian policy of legislature but in essence, are the inalienable human rights of them and other vulnerable groups in the society which are respected, acknowledged and guaranteed by the law; furthermore, such priorities are also directed towards social "vertical justice" - where there are different treatments to people with inborn differences or different living conditions, ensuring the true

\footnotetext{
${ }^{7}$ Refer to: N. H. Hang, T. D. Trung, New Stipulations on aged under 18 Offenders Adopted from January 1, 2018, https://kiemsat.vn/nhung-quy-dinh-moi-doi-voi-nguoiduoi-18-tuoi-pham-toi-ap-dung-tu-01-01-201848631.html; T. Moc, New Provisions on Minor Offenders, http://daibieunhandan.vn/ONA_BDT/NewsPrint.aspx?new sId $=340888$ and many articles in jurisprudence forums of Vietnamese criminal justice agencies claim that incentives given by the law to the juvenile show the humanity in law.
} 
equality among participants in proceedings, the equality in access to rights given to them by the law during their participation in criminal cases. It is required by the assurance of equality in terms of rights that the disadvantaged are the beneficiary of appropriate policies, legal measures given exclusively to them to keep them on the same level as others. Therefore, the State, through its agencies, persons competent to conduct criminal procedure, must create favorable conditions for the disadvantaged to acquire true equality and exercise their rights set out by criminal procedure law. The State must be responsible for ensuring equality before the law in criminal proceedings by setting up mechanisms for the disadvantaged to exercise and benefit from their rights, such as the mechanism which allows the participation of the representative, legal, psychological and medical assistant, etc.

Special care to juvenile aggrieved persons and the underprivileged in criminal justice does not conflict the principle of equality before the law but stems from the fact that these people suffer more disadvantages than others do in the society, and in the same criminal proceedings, they are more vulnerable in terms of health, dignity as well as other legitimate rights and interests. Thus, they need to be protected by proper and effective methods to reduce inequality, in other words, to be closer to equality. Article 8 of the Universal Declaration of Human Rights in 1948 (UDHR) affirms that "Everyone has the right to an effective remedy by the competent national tribunals for acts violating the fundamental rights granted him by the constitution or by law." Accordingly, the criminal justice system must provide mechanisms to protect the rights of juvenile aggrieved persons as well as of the disadvantaged by its own appropriate and effective rules. The current misunderstandings in Vietnam about the special legal status of juveniles in criminal justice being given thanks to the humanitarian nature of the State, or about juveniles being in a higher equality level than other proceedings participants are not really consistent with the world's approach and may result in a failure in the absolute and actual guarantee of the rights of juveniles in reality.

A question being raised is how the procedural obligations of juvenile aggrieved persons are set out compared with the adult aggrieved parties. For example, is a 10-year-old aggrieved person forced to give testimony if such compulsory act of testifying may hurt $\mathrm{him} / \mathrm{her}$. If juvenile aggrieved persons are bound by the obligation to testify, there may be a conflict between the principle of ensuring the best interests of juveniles and principle of determination of facts in a criminal case, as well as principle of mandatory prosecution in order to ensure social security. The solution adopted by Vietnam, a country with the crimecontrol model and mandatory prosecution, where common interests of society are the first priority, is to impose procedural obligation and obligation to participate in proceedings to determine the truth of the case on juvenile aggrieved persons, in the way that such obligations are minimized in compared with those of the adult aggrieved parties, and towards in a procedure-friendly mechanism with representatives, support persons and no commitment to honest testimony.

When the juvenile accused is presumed to commit crime and the aggrieved persons are juveniles, a conflict of law may arise as to whether the juvenile accused or juvenile aggrieved persons should be prioritized because the priority given to one person may be a disadvantage to the others, while in principle, they are all equal before the law and their best interests must be ensured in juvenile justice. For example, not being subject to detention is beneficial to the juvenile suspects but may be detrimental to the juvenile aggrieved persons. The answer, therefore, must come from the concrete circumstances and the first priority for the principle of presumption of innocence in order to ensure human rights of the accused in criminal procedure. This is the key to solve such legal conflict, which requires the procedure-conducting agencies to answer all questions about the legal basis of decision on detention of suspects (the possibility of causing 
harm to victims and the community if the suspects are not detained, harm to the juvenile suspects themselves if they are detained, and whether detention is the last resort applied to the accused in accordance with the principle of presumption of innocence).

\section{Issues to be Raised for The Improvement of Law on Juvenile Victims in Vietnam}

\subsection{Juvenile Victims in Vietnamese Traditional and Contemporary Legal Culture}

3.1.1. Juvenile Victims as a Part of the Crime Victims

In the Vietnamese legal history, the rights of crime victims have been acknowledged to a certain extent, reflecting the features of legal culture of Vietnam, which upholds the public interests, follows the crime-control model with the highest goal of protecting the common interests of society against criminal acts but also attaches significance to social harmony and stability. Therefore, Vietnamese traditional legal culture places high value on the right to denunciation of victims, but also encourages conciliation, and attaches importance to the informal settlement and conciliation institutions in the community. The rights of crime victims are regulated in various legal sources of the State, and several rights of the victims are mentioned in customary laws [6;288], showing the concern of the village and "grassroots democracy" nature for victims of crime. The rights of victims are directly regulated (specific rights) as well as indirectly regulated (responsibilities and obligations assumed by the central and local authorities to protect corresponding rights of the victims in the process of resolving criminal cases).

The rights of victims and protection of victims in the history of Vietnamese law can be generalized in some primary aspects (basic groups of rights), namely: right to accusation and participation in the proceedings against offenders [7; Chuong Doan nguc (Chapter on Jail) Article 16] and [7; Article 303]; right to withdraw requests for criminal prosecution against the offenders prescribed in "Le ve quan xet an, Quoc trieu kham tung dieu le" (Regulations on Mandarins in charge of Hearing Cases, in National Rules on Criminal Proceedings) $[8 ; 478]$; right to compensation under the provisons of "Le so 12 - Le thu tien chuoc, tien phat, tien boi thuong và tien ta, Bo Quoc trieu kham tung dieu le" (Regulation 12 Regulation on ransom, fines, compensation and reward of the National Regulations on Investigation and Proceedings) [8; 738]; right to be taken care of and fostered by the family of the offenders and community [7; Chuong Dau tung (Chapter on Litigation) Article 4]. The rights to accusation, request for punishment by the law applied to offenders are clearly recognized with specific responsibilities in the acceptance, handling and punishment of offenders of multi-level authorities; however, there are some limitations to such rights of the victims due to the conservatism of the feudal State and village community, which discouraged litigation in order to maintain social stability. Therefore, the crime victims' right to "withdraw a petition" is respected but also restricted if they are victims of criminals violating feudal moral values. The right to claim for compensation of victims was recognized and guaranteed to be exercised with the reasonable expansion of "fines" - joint responsibility in certain cases. The victims' right to be cared for and cured by the offenders themselves and their family is also a rational and humane regulation of medieval law. Several regulations in ancient customary law on the responsibilities of villages in supporting and caring for victims of crime and wandering children show both the tradition of mutual affection and sense of community in rural areas of Vietnam. However, in general, a number of rights of victims were nowhere to be found in the history, especially procedural rights in legal proceedings such as right to equality in presenting evidence, material, objects, in making requests and debating in due manner before the court, right to self-defense, the right to have their rights protected by other people, the right to participate in procedural activities, 
right to request the protection of life, health, dignity and property in case of existing threats, which have not been regulated or specified. This lack of rights stems from limited procedural legislative capacity, limited cognitive ability in relation to human rights issues and both the restrictions on procedural type and model in the general restriction of the history.

In the current Criminal procedure Code 2015, the rights of victim are primarily regulated in Article 62 (victims as the aggrieved parties) and Chapter 34 titled Procedure for protecting denouncers, witnesses, the aggrieved parties and participants in proceedings. In addition, several regulations on protecting victims are shown in Law on drug prevention 2008 (Articles 13, 14), Law on human trafficking prevention 2011 (Article 6), Law on domestic violence prevention 2007, regulations on legal aid right for a limited number of victims in the Law on legal aid 2017, regulations on compensation (tort) provided in Civil Code 2015. In terms of quantities, the establishment of such rights has referred to international standards on victims' rights. The rights of the aggrieved parties normally include group of rights to personal security, right to legal, psychological, medical assistance, group of procedural rights and group of rights to compensation.

i) Group of rights to ensure safety and receive necessary legal, psychological, and medical assistance. The need to protect the safety of victims arises as these victims are always at potential risks of continuing to be abused by offenders or from other people related to thereof and initial offence. Without the protection by the law, the safety of victims can be threatened or seriously threatened. In addition to such right, victims are entitled to essential supports. These supports are mainly medical, psychological, legal support if the victim satisfies certain requirements (such as being eligible to receive legal aid or, victims of certain types of crime). This group of rights is set out in different laws, not only in criminal procedure law. ii) Group of oral argument right of victims. The rights to get involved in adversarial process of victims include right to have access to details of the case; right to engage in evidencegathering process; right to make requests in the process of resolving a case (right to request a prosecution, withdraw a request to prosecute a criminal case; right to present documents, objects, requests; right to give opinion on related evidences, documents, objects and request person who is competent to conduct procedures to examine and evaluate; right to attend a court hearing, give opinion, request the presiding judges to ask the defendants and other participants in the court hearing; argue in the court hearing to protect their rights and interests; see the trial minutes; right to propose penalties, compensation, compensationprotective measures, etc.). These rights are set out in criminal procedure code.

iii) Group of rights to compensation. Accordingly, victims will be subject to compensation by the ones who committed the acts of doing harm to their lives, health, honor, dignity, prestige, property, legitimate rights and interests based on the principle of full and prompt compensation for actual damage. These rights are set out in the civil law.

3.1.2. Juvenile Victims as a Part of the Juvenile Participants in Criminal Procedure

It can be said that concerns given to their rights are not really sufficient. The rights of juvenile aggrieved persons are mainly exercised by those who play the role of patriarch in the family owing to a legal culture strongly influenced the Confucian thought that gives high appreciation to such role. That patriarch is conferred special power to other family members, to represent other family members (including the juvenile) does not merely means the low standings of the juvenile but also shows the obligation and concern of patriarch persons to the juvenile, even though they think, they do and they decide instead of the juvenile. Such role of patriarch persons stem from the responsibility to their children as well as the responsibility to society since the juvenile cause harm to society due to their poor education. 
Besides, in a legal system of which procedural laws are not fully developed and mainly concerned about substantive justice but not procedural justice, procedural rights of the participants in proceedings in general and of the juvenile participants in particular have not been fully recognized.

In the modern criminal procedural law, juvenile aggrieved persons have not been given adequate attention. The Criminal Procedure Code of 1988 and 2003 established a special procedure for the arrested, the ones held in temporary custody, the accused, juvenile defendants, titled "Criminal proceedings for the juvenile", but no regulation on juvenile aggrieved persons has been made. It is not until the introduction of Joint Circular 01/2011/TTLT-VKSTC-TANDTC-BCA-BTPBLDTBXH of the Supreme People's Procuracy, Supreme People's Court, Ministry of Public Security, Ministry of Justice, Ministry of Labor - Invalids and Social Affairs guiding the implementation some provisions of the Criminal Procedure Code 2003 on 12 November 2011 (here referred to as "Joint Circular 01"), that the definition of juvenile participants in the proceedings, regulations on the rights of juvenile aggrieved persons were first introduced and in the Criminal procedure Code 2015 taking effect from 1/1/2010, juvenile aggrieved persons are given specific rights in a Criminal Procedure Code. Up to the Criminal Procedure Code 2015, the "procedure for juveniles" is officially expanded to not only the accused but also other participants namely the aggrieved parties, witnesses, named "Criminal proceedings for under-18 people". The expansion of the scope of application for both the aggrieved persons and witnesses under 18 was a significant enhancement of the Criminal Procedure Code 2015, which leaned towards strengthening the protection of human rights in general and the under 18 in particular. Thus, the under 18 who are the accused, aggrieved, witnesses in proceedings will follow a special procedure and it shall be applied only in cases where the accused, aggrieved or witnesses are under 18. Up to now, together with Circular no. 02/2018/TT-TANDTC dated 21/9/2018 of the Chief Justice of Supreme People's Court detailing the resolution to criminal cases where there are minor participants under the jurisdiction of juvenile and family court, Joint Circular no. 06/2018/TTLT-VKSTC-TANDTC-BCA-BTPBLDTBXH dated 21/12/2018 guiding the implementation some provisions of the Criminal procedure Code about people under 18 (hereinafter referred to as "Joint Circular 06 "), objectively speaking, despite being issued late, has made considerable progress in the course of approaching international standards on juvenile justice, so the juvenile aggrieved persons are not ignored as they were before 2011. The rights of juvenile aggrieved persons as juvenile participants in proceedings can be generalized as follows: first, there are common rights for juvenile participants in proceedings; second, there are separate rules for juvenile aggrieved persons. To be specific, they are entitled to common rights conferred to juvenile participants in proceedings - to policies and guarantee aiming at improving the weaker position and minimizing the vulnerability of juveniles in criminal proceedings. These are:

i) Ensuring a child-friendly approach in proceedings, in accordance with psychology, age, maturity, awareness of the juvenile on the basis of ensuring the best benefits of the juvenile. This principle requires all processes, proceedings, procedural conductors, facilities and technical facilities for litigation activities to be adequate for their psychology and age. Ensuring the right to appropriate treatment for their psychology and age requires a friendly procedural apparatus with persons authorized to conduct proceedings who have knowledge of juvenile psychology, of educational science, communication skills, respect to juveniles; the process of taking testimony, and interrogation requires the content and method of questioning to be suitable to the maturity level and awareness of juveniles.

ii) Ensuring the right to participate in proceedings of the representatives of juveniles, schools, youth union, experts in social 
psychology, other organizations where juveniles are studying, working and living; respect the right to give opinion of juveniles.

iii) Ensuring the right to defense, right to legal aid of juveniles. This regulation derived from the right to fair treatment, the principle of ensuring litigation for the juvenile - the group of people who are vulnerable and unable to legally perform self-defense, self-protection compared to other age groups.

Besides, criminal cases involving juveniles as participants in proceedings are more guaranteed than other criminal cases in terms of: iv) ensuring personal confidentiality of the juvenile because they are vulnerable, likely to have an inferiority complex about their mistakes or body defects or personal life, so when conducting proceedings involving under18 people, the authorized agency must keep their secrets confidential; v) ensuring timely settlement of cases relating to the juvenile to reduce psychological trauma caused by prolonged proceedings.

Therefore, juvenile aggrieved persons have the rights of juvenile participants in proceedings, with 5 specific groups of rights for juvenile participants in proceedings as mentioned above. Additionally, they, as juvenile aggrieved persons, are also entitled to special rights, shown in provisions of Circular no. 06 on responsibility of the competent authorities in coordinating timely to settle cases where the under-18 aggrieved are sexually abused, abused or trafficked; In case of taking testimony, priority must be given to the residence of such persons as the location of taking testimony; if there is no place of residence, it must be conducted at a child care center in accordance with the law and conducted immediately after information about crime is received. With regard to obligations of juvenile aggrieved persons, the Criminal Procedure Code 2015 does not directly set out obligations of juvenile aggrieved persons in particular and juvenile participants in general but according to Article 413, "Legal proceedings for accused persons, individuals aggrieved and witness testifiers who are less than 18 years old shall be governed by this Chapter and other regulations of this Law not contrary to those in this Chapter", which means that in the event of no specific provision in the chapter "Criminal procedure for the under 18", general regulations in the Criminal Procedure Code 2015 shall be applied and juvenile aggrieved persons shall be given the obligations of the aggrieved parties generally.

\subsection{Enhancing the Law on Juvenile Victims during the Process of Adopting International Law}

Through theoretical analysis based on the aspect of relations in part 1 and part 2 of the article as well as the survey on provisions of contemporary legal status of juvenile aggrieved persons as mentioned in 3.1 with specific regulations/standards of international human rights law on victims' rights and regulations on the rights of the juvenile, it can be considered that the improvement of Vietnam's law on juvenile aggrieved persons calls for further study and solution to the following issues:

3.2.1. From the Perspective of Enhancing the Law on Victims in the Process of Accepting International Laws on Victim

First, the rights to medical, psychological and legal support to victims of crime need to be more fully recognized (implementing recommendations on "Assistance" specified in section 14, 15, 16, 17 of the "Declaration"). In current law of Vietnam, the rights to medical, psychological, legal, and financial support, despite being introduced, are still limited. Only a number of victims are entitled to legal aid; institution for the implementation of support for victims of crime is primarily set out for victims of domestic violence in terms of health, psychology and law. Article 13 of "Joint Circular 01" of 2011 regulated quite clearly the assistance on dwelling, health care, legal aid and psychological support for juvenile aggrieved persons. However, in "Joint Circular 06" of 2018 replacing "Joint Circular 01", provisions on these assistances are not more detailed and also unclear. 
Second, the rights to be paid for procedural expenses and to compensation to victims of crime need to be recognized. Payment for procedural expenses and compensation to victims of crime from state budget are unfamiliar in Vietnam law. As for the payment for procedural expenses, only witnesses have the right to "be paid by the summoning agency for travel expenses and other expenses as prescribed by law" [7; Article 66] while the aggrieved parties do not have such right. Payment for procedural expenses or reimbursement of expenses, as European standards, "victims who participate in criminal proceedings, the possibility of reimbursement of expenses incurred as a result of their active participation in criminal proceedings, in accordance with their role in the relevant criminal justice system. The conditions or procedural rules under which victims may be reimbursed shall be determined by national law" [9; Article 14]. There have been different academic arguments in Vietnam on compensation for victims of crime (whether it should be "compensation" or "restitution" or "reparation" or another legal term). However, the nature of the problem is that the State is responsible for compensating for victims of crime because the State has not fully completed its responsibility to ensure security and safety for citizens, in order to compensate for a part of the damage caused by crimes. "Rule-of-law State is the state that is responsible for all its activities, which is the moral principle of the state before the society. The more modern and civilized the society is, the higher and more complete and comprehensive responsibility it is required for the subjects, including the state. The State must be the embodiment, the model of the most complete responsibility in the society" [10]. The current law of Vietnam has not prescribed the compensation of the State for victims of crime. The responsibility for compensation being attributed to the State shows a great humanity, especially in the case specified in Article 12 of "Declaration". It is obvious that in order for this regulation to be issued, a thorough study of grounds, jurisdiction, procedures budget allocation for compensation is needed, as well as "Judicial and administrative mechanisms should be established and strengthened where necessary to enable child victims to obtain redress through formal or informal procedures that are prompt, fair and accessible" [11; Section 47].

Third, regulations on the right to be informed and consulted on applying penalties, criminal proceedings, exemptions during criminal sentence enforcement. The aggrieved parties in Vietnam currently have not had access to information on the custody of offenders, unlike in other countries ${ }^{8}$, or to be more elaborated, they have not been given the right to be informed and consulted on the application of criminal justice enforcement measures such as imprisonment, suspended sentence, probation, parole, and the right to be informed and consulted on the application of criminal procedural enforcement measures such as temporary detention and replacement, cancellation of temporary detention and prohibition of leaving the residence. For example, before deciding to change temporary detention with a guarantee, the victim will be consulted to determine the consequences of being subject to bail to the victim's safety and the victim's psychology. The laws of many countries around the world have defined this kind of rights for victims as well as the obligations from competent authorities in the proceedings. This is very significant for victims, especially in cases where both victims and offenders live together in a community. In addition, various rights of being informed have been stated in Vietnam law but regulations on implementing these rights needs further completion such as communicating with simple and easily-accessed language, receiving timely notice of the case and the rights, giving testimony and opinions by their own language.

\footnotetext{
8 Refer to: The Massachusetts Victim Bill of Rights (M.G.L. c. 258B, http://www.mass.gov/servicedetails/victim-bill-of-rights), The California Victims' Bill of Rights (Marsy's Law.

https://www.sdcda.org/helping/victims/victim-rights), and other states of Australia and Canada.
} 
3.2.2. From the Perspective of Enhancing the Criminal Procedural Law on Juvenile Aggrieved Persons in the Process of Accepting International Law on Juveniles in Criminal Justice

Fourth, the right to communicate, voice out as well as the right to have their privacy respected of juvenile aggrieved persons (implementing the principles of 3, 4, 5, 6 of 6 basic principles specified in the Model law) should be more fully acknowledged. These are two branches of rights that tend to be contradictory but are the rights of juveniles being overlooked because juveniles are often regarded as "having no awareness" or having their adults thought, spoken or done instead according to Confucian culture where rights of the patriarch are respected and rights of children and women are underestimated. According to principle 6 of the Model Law, victims or child witnesses "have the right to express their views, opinions and beliefs freely, in their own words".

On the other hand, the sense of attaching importance to personal privacy, especially the privacy of children, has not been clearly shaped in contemporary Vietnamese culture. The right to respect for privacy is stipulated in Clause 2, Article 414 of the Criminal procedure Code "to ensure the confidentiality of the under 18 " but in addition to some provisions on trial procedures for the court hearing to respect such privacy, during the case settlement process, how privacy is respected has not been specified. Meanwhile, this right was seriously introduced in Model law, requiring "the Interference in the child's private life to be limited to the minimum necessary as defined by law", "information that may identify the child as the aggrieved persons or witness will not be disclosed without the court's permission". Such international standards of the "Directive" as using audiovisually recorded interviews with juvenile victims as evidence instead of bringing them to court for directly taking testimony, establishing the necessary conditions to enable avoidance of contact between victims and the offenders... have not been introduced in Vietnam.
Fifth, obligations of juvenile aggrieved persons should be reduced compared to that of the aggrieved persons being adults. Obligations of the aggrieved persons as defined in article 62 of the Criminal procedure Code are: i) be present as per authorized procedural persons' subpoena and ii) Abide by competent procedural authorities and persons' decisions and request. The current Criminal procedure Code does not have any specific regulations for juvenile aggrieved persons, so it may lead to a perception in which juvenile aggrieved persons have no duties or have all duties of the aggrieved parties in general. The two ways of understanding are extreme, and juvenile aggrieved persons need duties but such duties are reduced compared to these of the aggrieved parties being adults and there is the participation of the representatives and third persons to support the aggrieved parties when they perform their obligations in more friendly proceedings.

Sixth, view on presumption of age of the victim needs to be clarified by legislature. The age of the aggrieved persons had been presumed contrary to the regulations in Article 417 of the Criminal procedure Code 2015 and the "Joint Circular 06". The two documents now provide provisions of cases where legitimate measures have been applied but only determined the month, quarter, first or last half of the year or year of birth then the end of the month, quarter, first half or last half of the year or year of birth will be used to determine their age. In case the age assessment result only shows the age range of the accused, the aggrieved parties, the agencies or people authorized to conduct legal proceedings shall take the smallest age in the defined age range as their age. For instance, according to examination, if the age of $\mathrm{A}$ ranges from 13 years old and 6 months to 14 years old and 2 months, 13 years old and 6 months shall be the age of A. Previous sub-law documents demonstrated two cases and the age of the aggrieved persons was counted from the beginning of the month, quarter, first or last half of the year or year of birth to determine their age (as opposed to that of the accused). 
The same identification of age as provided in the Criminal procedure Code 2015 and "Joint Circular 06 " is only appropriate to determine the age of the accused and in favor of the accused (the accused is more likely to be under 14,16 or 18 and only beneficial to the aggrieved persons when they are more likely to be under 14,16 or 18 . However, as the legislature fails to interpret the view on presumption of age of the victim, the current regulations may be considered to violate the principle of presumption of innocence or a proof of presumption of guilt. If not, with such presumption of age, Vietnam accepts to "overturn" the principle of presumption of innocence (in favor of the accused) to provide exception for the victim (in favor of the "child" victim), similar to the present perspective of European [13; Article 25.2].

Last, it is essential for Vietnam to draft an act on victims of crime in order to set out general rights of victims, establish institutions for ensuring such rights (such as state agencies, civil organizations in charge of supporting victims and the operation of such institutions), close loopholes in current legal regulations on rights of the crime victims who have not been recognized as aggrieved party in criminal procedure, and to set certain mechanisms to safeguard victims of vulnerable group, including juvenile victims.

\section{Conclusion}

In Vietnamese criminal justice, juvenile victims are a part of victims of crime, but are not automatically recognized as the aggrieved persons in criminal proceedings When being granted the aggrieved party status, juvenile aggrieved persons are among the juveniles who participate in proceedings and have almost all rights of the juvenile participants in proceedings, except for the rights of the juvenile accused. The rights of juvenile aggrieved persons are the combination of these two statuses, which are the rights of the aggrieved parties and rights of the juvenile to ensure the substantive equality, "vertical justice" in criminal procedure. However, procedural obligations of juvenile aggrieved persons have not been questioned and solved by lawmakers and the mechanism to settle the conflict of the rights of juvenile aggrieved persons and of the principle of presumption of innocence has not been fully interpretation.

This paper indicates a positive progress in the legislation on the rights of victims and juvenile participants in proceedings in Vietnam in order to catch up with norms and standards of the international human rights law but there is still a big gap in between. In order to narrow such gap, this paper suggests learning from some regulations on the rights of victims and of juveniles in criminal justice (according to international human rights law, on the basis of the aforesaid theoretical analysis).

As its focus is the foregoing content, this paper has not adequately evaluated actual conditions of Vietnam (in order to keep on learning from international law on the rights of the juvenile victims). These issues need to be raised in further studies.

\section{References}

[1] L. T. Son, Textbook on Criminology, People's Public Sercurity Publish House, Hanoi, 2012 (in Vietnamese).

[2] UN. General Asembly, Resolution 40/34, Declaration of Basic Principles of Justice for Victims of Crime and Abuse of Power, 1985, https://www.ohchr.org/en/professionalinterest/pa ges/victimsofcrimeandabuseofpower.aspx. (last accessed on 02/03/2021).

[3] The Vietnam Criminal Procedure Code of 2015 (in Vietnamese).

[4] Ministry of Labor, War Invalids and Social Affairs, UNICEF Vietnam, Juvenile Justice Training Manual, Labor Publish House, Hanoi, 2012 (in Vietnamese).

[5] Judicial Academy, Textbook on Hearing of Criminal Cases, Justice Publish House, Hanoi, 2004 (in Vietnamese).

[6] L. D. Tiet, About Village's Internal Regulations, National Political Publish House, Hanoi, 1998 (in Vietnamese).

[7] National Penal Code of Le Dynasty (in Vietnamese). 
[8] The Vietnam Social Science, Institute of SinoNom Studies, Legal Instruments of Vietnam from 15th Century to 18th Century, Vol. 1, Social Science Publish House, Hanoi, 2006 (in Vietnamese).

[9] The European Parliament and the Council, Directive of Establishing Minimum Standards on the Rights, Support and Protection of Victims of Crime, 2012, https://eur-lex.europa.eu/legalcontent/en/TXT/?uri=CELEX\%3A32012L0029 (last accessed on 02/03/2021).
[10] T. T. Duong, The State's Liability for Compensation: Idientified and Distingushed from Indemnity, Legislation Research, 5 (142), 2009, 30 (in Vietnamese).

[11] UN. ECOSOC, Guidelines on Justice in Matters involving Child Victims and Witnesses of Crime, 2005, https://www.un.org/ruleoflaw/blog/document/gui delines-on-justice-in-matters-involving-childvictims-and-witnesses-of-crime/ (last accessed on 02/03/2021). 